\title{
ANALISIS HUBUNGAN KINERJA PASAR MODAL ASEAN DENGAN PASAR MODAL INDONESIA PERIODE 2015 - 2019
}

\author{
Neneng Puji Asih, Yuslinda Nasution \\ Nenengpuji98@gmail.com \\ *) Dosen Tetap Program S1 Jurusan Manajemen Fakultas Ekonomi dan Bisnis \\ Universitas Satya Negara Indonesia
}

\begin{abstract}
This study is to determine the relationship between the performance of the ASEAN Capital Market and the Indonesia Capital Market for the 2015-2019 period. The population in this study were all ASEAN countries. The research sample is ASEAN-5 countries, namely Singapore, Malaysia, Phillipine, Thailand and Indonesia with the purposive sampling method as a sampling technique. Hypothesis testing in this study uses multiple linier regression analysis. The results of this study indicate partially only the Strait Time Index of Singapore which has no significant effect on the Jakarta Composite Index of $(0.460>0.05)$. Jakarta Composite Index, Stock Exchange of Thailand 0.000 has significant effect on Jakarta Composite Index, the result also show that tha Strait Time Index. Kuala Lumpur Stock Exchange, Phillipine Stock Exchange and Stock Exchange of Thailand simultaneously influence the Jakarta Composite Index.
\end{abstract}

Keywords: Strait Time Index, Kuala Lumpur Composite Index, Phillipine Stock Exchange, Stock Exchange of Thailand, Jakarta Composite Index.

\section{PENDAHULUAN}

Negara Indonesia sebagai Negara yang sedang berkembang, dimana dalam proses perkembangannya pasti akan membutuhkan modal atau dana dalam jumlah yang besar sebanding dengan pertumbuhan yang ditargetkan. Dalam hal ini pasar modal mempunyai peranan yang strategis dalam perekonomian Indonesia, pasar modal merupakan salah satu pilar ekonomi Indonesia yang dapat menjadi penggerak ekonomi nasional melalui peranannya sebagai sumber pembiayaan bagi perusahaan dan alternative bagi para pemodal.

Pasar modal mengacu pada semua lembaga dan prosedur yang menyediakan instrument keuangan jangka panjang. Jangka panjang di sini berarti memiliki periode jatuh tempo yang lebih dari satu tahun. Dalam arti luas, saham perusahaan, dan obligasi. Dengan adanya integrasi, indeks harga saham akan menjadi lebih stabil, sehinggga resiko yang timbul hanyalah resiko sistematis. Sejalan dengan itu, pasar yang sistematis ini akan menjadi pasar yang efisien, bahwa pasar yang terintegrasi lebih efisien dibandingkan dengan pasar yang tersegmentasi. Dengan demikian pasar akan terhindar dari adanya penyimpangan harga baik itu overpriced maupun

underpriced. Integrasi pasar modal sendiri dapat disebabkan oleh berbagai faktor. Lebih singkatnya dapat dikatakan jika integrasi pasar modal disebabkan oleh adanya integrasi ekonomi. Integrasi ekonomi merupakan penghapusan hambatan dan pengurangan diskriminasi sebagai sebuah kebijakan komersial yang berlaku secara khusus untuk pihak yang tergabung dalam 
integrasi tersebut. Hubungan antara pasar modal dari negara Singapura, Malaysia, Filipina dan Thailand dengan pasar modal Indonesia sudah layak diintegrasikan ataukah masih tersegmentasi.

Selanjutnya perlu juga diketahui dan dibuktikan bentuk integrasi seperti apa yang terjadi: apakah suatu pasar modal hanya mempengaruhi pasar modal yang lain,atau suatu pasar modal hanya dipengaruhi oleh pasar modal yang lain, atau suatu pasar modal selain mempengaruhi juga dipengaruhi oleh pasar modal yang laindalam satu kawasan ASEAN-5.

Tujuan Penelitian :

Tujuan penelitian kali ini untuk mengetahui apakah kinerja pasar modal Singapura, Malaysia, Filipina dan Thailand mempunyai hubungan dengan kinerja pasar modal Indonesia.

\section{TINJAUAN PUSTAKA}

\section{Pasar Modal}

Pasar Modal merupakan pasar kauntungan untuk transaksi dana jangka panjang daan merupakan pasar yang konkret. Pasar modal adalah tempat di mana pihak khususnya perusahaan menjual saham (stock) dan obligasi (bond) dengan tujuan dari hasil penjualan tersebut nantinya akan dipergunakan sebagai tambahan dana atau untuk memperkuat modal perusahaan (Fahmi, 2015).

\section{Saham}

Saham merupakan tanda kepemilikan dari perusahaan yang mewakili kepada manajemen untuk menjalankan operasi perusahaan (Jogiyanto, 2015 :174). Saham juga dapat diartikan sebagai tanda penyertaan atau pemilikan seseorang atau badan dalam suatu perusahaan, dimana pemilik saham atau yang disebut investor menjadi pemilik perusahaan tersebut sebesar modal yang ditanamkan.

\section{Harga Saham}

Harga saham merupakan nilai saham dari selembar saham yang diterbitkan oleh emiten. Harga saham adalah informasi utama yang diperlukan oleh investor, karena harga saham merupakan cerminan dari kinerja suatu perusahaan (emiten).

Menurut Tandelilin (2013 : 144), harga saham merupakan cerminan dari ekspektasi investor terhadap faktor earning, aliran kas dan tingkat return yang disyaratkan investor, yang aman ketiga faktor tersebut juga sangat dipengaruhi oleh kinerja ekonomi makro.

\section{Indeks Harga Saham}

Pengambilan keputusan membutuhkan data historis menegenai berbagai kejadia di masa lalu. Keputusan investor dalam memilih suatu saham sebagai obyek investasinya membutuhkan data historis terhadap pergerakan saham yang beredar di bursa, baik secara individual, kelompok, maupun gabungan. Bentuk informasi historis yang dipandang sangat tepat untuk menggambarkan pergerakan harga saham di masa lalu adalah suatu indeks harga saham yang memberikan deskripsi harga-harga saham pada suatu saat tertentu maupun dalam periodesasi tertentu pula.

\section{Integrasi Pasar Modal}

Menurut Mailangkay (2013 : 723) Integrasi pasar modal merupakan suatu keadaan dimana hargaharga saham di berbagai pasar modal dunia mempunyai hubungan yang sangat dekat (closely 
correlated) antara suatu pasar modal dengan pasar modal lainnya di dunia, sehingga pasar modal di dunia dapat mencapai suatu harga international (international Pricing) atas saham saham mereka dan memberikan akses yang tidak terbatas atau hambatan apapun kepada para investor di seluruh dunia untuk memilikinya.

\section{Bursa Efek Kawasan ASEAN}

ASEAN (Association of Southeast Asian Nations) merupakan organisasi perhimpunan negaranegara yang berada di kawasan Asia Tenggara. Kawasan Asia Tenggara mencakup IndoChina dengan republic rakyat Tiongkok di sebelah utara, samudra pasifik di timur, samudra Hindia di selatan, dan Samudra Hindia, teluk Benggala, dan anak benua di barat (asean.org).

\section{ASEAN-5}

ASEAN-5 merupakan negara-negara pendiri kelompok ASEAN pertama, yaitu Indonesia, Filipina, Malaysia, Singapura dan Thailand. Menurut riset Deutsche Bank (2006), negara-negara ASEAN-5 memili potensi yang besar untuk bisnis, perdagangan dan investasi dan memiliki ukuran ekonomi gabungan sebesar USD 750 juta dan pendapatan per kapita sekitar USD 1.800, sedikit lebih besar dari cina dan lebih dari dua kali lipat India.

\section{Penelitian Terdahulu}

Menurut hasil dari penelitian Rasyidin (2016) dengan judul Integrasi Pasar Modal Asean Pasca Pemberlakuan MEA mengatakan bahwa speed of adjustment yang signifikan menunjukan bahwa guncangan disequlibrium akibat perubahan pasar modal dalam jangka pendek langsung dapat diperbaiki kembali menuju equilibrium pada periode berikutnya. Pada pasar modal Filipina dalam jangka pendek berpengaruh negatif terhadap perubahan/pergerakan pasar modal

Indonesia. Pengaruh negatif menunjukkan bahwa menurunnya pergerakan harga saham di pasar modal Filipina dalam jangka pendek direspon oleh pelaku pasar modal (investor) dengan mengalihkan investasinya ke pasar modal Indonesia.

Menurut hasil dari penelitian Ardina Puspitasari, Hermanto Siregar dan Trias Anandati (2015) dengan judul Ananlisis Integrasi Bursa Saham ASEAN -5 mengatakan bahwa terdapat integrasi atau hubungan jangka panjang dalam kawasan ASEAN5 (Indonesia, Malaysia, Singapura, Thailand, dan Filipina).

Dalam hubungan jangka panjang, diperoleh bahwa hanya Thailand dan Singapura yang secara signifikan mempengaruhi pasar saham Indonesia.

Menurut hasil dari penelitian Luh Gede Sriartini, Nyoman, Putu Vivi Lestari (2017) dengan judul Analisis Fundamental Makro dan Integrasi Pasar Saham Dunia Dengan Bursa Efek Indonesia mengatakan bahwa PDB berpengaruh positif signifikan terhadap IHSG mengindikasikan pertumbuhan ekonomi, semakin tinggi PDB berarti pendapatan masyarakat meningkat, Meningkatnya PDB merupakan sinyal yang baik (positif) untuk investasi dan sebaliknya. Meningkatkan PDB mempunyai pengaruh positif terhadap daya beli konsumensehingga dapat meningkatkan permintaan terhadap produk perusahaan.

Menurut Hasil Penelitian dari Jurgen H. Waworendeng, Paulina Van Rate (2018) dengan judul Analisis Hubungan Pasar Modal ASEAN dengan Pasar Modal Indonesia di Bursa Efek Indonesia mengatakan Indek kelima pasar modal diketahui Korelasi Pearson antara bursa Indonesia Kuala Lumpur Stock Exchang menunjukan bahwa antara bursa Malaysia dan bursa Indonesia tidak 
terdapat hubungan yang signifikan dimana nilai sig. hasil uji korelasi pearson pada SPSS yaitu (lebih dari 0.05) menandakan hubungan signifikan.

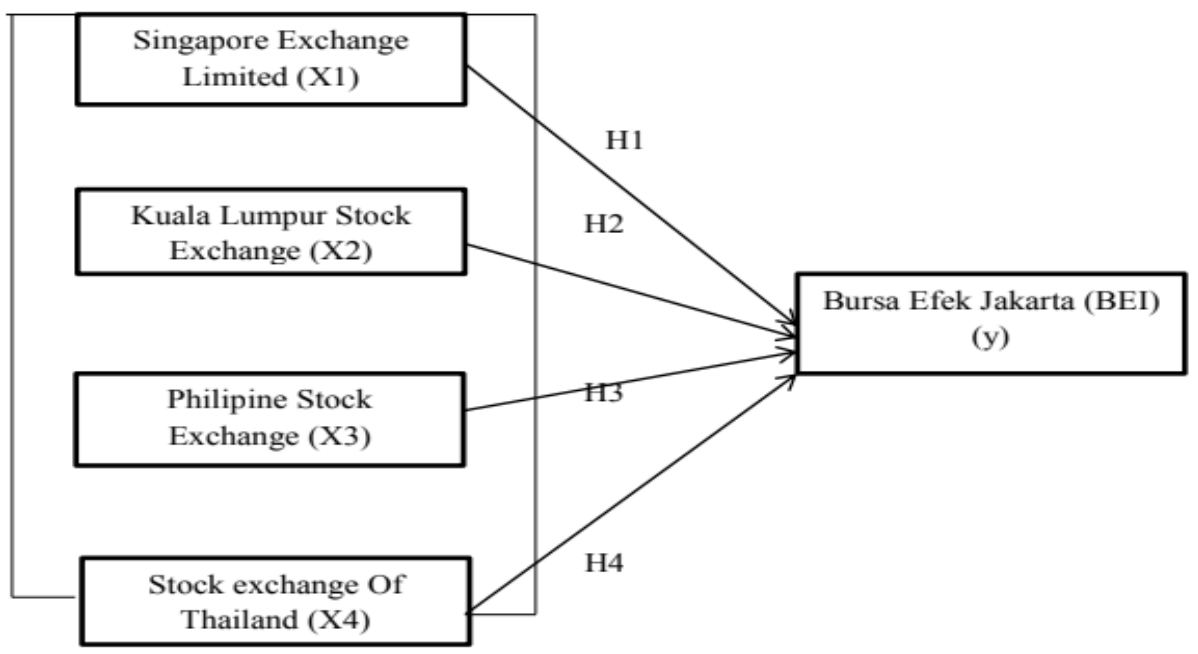

Gambar 1. Kerangka Konseptual

Sumber : Konsep yang dikembangkan dalam penelitian ini, 2020

\section{Hipotesis Penelitian :}

H1 : Strait Time Index Singapura mempunyai hubungan dengan kinerja Indeks Harga Saham Jakarta Composite Index

H2 : Kuala Lumpur Composite Index (Malaysia) mempunyai hubungan dengan kinerja Indeks Harga Saham Jakarta Composite Index

H3 : Philipine Stock Exchange mempunyai hubungan dengan kinerja Indeks Harga Saham Jakarta Composite Index

H4 : Stock Exchange Of Thailand mempunyai hubungan dengan kinerja Indeks Harga Saham Jakarta Composite Index

\section{METODE PENELITIAN}

\section{Data dan Sumber Data}

Jenis penelitian yang digunakan berupa jenis penelitian dengan menggunakan data sekunder berupa data Bulanan dari Index Harga Saham Gabungan dari 5 pasar modal Negara-negara anggota ASEAN-5. Ke 5 index pasar modal tersebut antara lain adalah Jakarta Composite Index, Strait Time Index Singapura, Kuala Lumpur Composite Index, Philipine Stock Exchange dan Stock

Exchange Of Thailand: Index-index harga saham yang digunakan mencakup periode bulanann dari tahun 2015 - 2019. Sumber data yang digunakan dalam penelitian ini adalah data sekunder yang diperoleh dalam bentuk dokumentasi Index bursa dari 5 negara yang tergabung dalam ASEAN-5 di (www.investing.com). 


\section{Metode Pengumpulan Data}

Penelitian akan dilakukan di galeri Investasi Bursa Efek Indonesia yaitu dengan cara mengunduh data laporan keuangan bulanan dari ke 5 pasar modal dari tahun 2015 - 2019 selama periode penelitian yaitu bulan Januari 2015 - Desember 2019.

\section{HASIL PENELITIAN DAN PEMBAHASAN}

\section{Uji Asumsi Klasik}

\section{Uji Normalitas}

Tabel 1. Uji Normalitas Residual

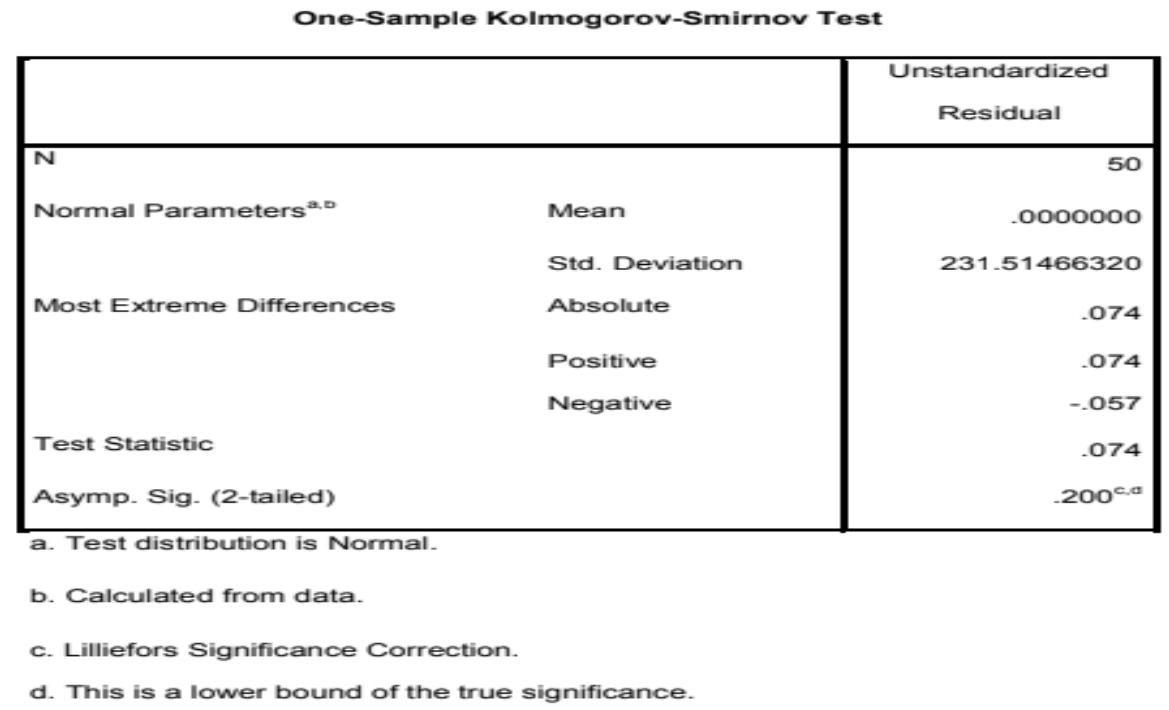

Sumber:Data Diolah, (2020)

Berdasarkan tabel 1. diatas dapat diketahui bahwa nilai signifikan residual pada 50 data tersebut adalah 0.200 atau lebih $>0.05$. hal ini berarti $\mathrm{HO}$ diterima atau dengan kata lain bahwa nilai residual tersebut berdistribusi normal.

\section{Uji Autokorelasi}

Tabel 2. Hasil Uji Autokorelasi

\section{Model Summary ${ }^{b}$}

\begin{tabular}{|l|r|r|r|r|r|}
\hline Model & \multicolumn{1}{|c|}{$\mathrm{R}$} & R Square & \multicolumn{1}{c|}{$\begin{array}{c}\text { Adjusted } \mathrm{R} \\
\text { Square }\end{array}$} & $\begin{array}{c}\text { Std. Error of the } \\
\text { Estimate }\end{array}$ & Durbin-Watson \\
\hline 1 & $.902^{\mathrm{a}}$ & .813 & .796 & 241.585 & .996 \\
\hline
\end{tabular}

a. Predictors: (Constant), SET, KLCl, PSE, STI

b. Dependent Variable: JKSE

Sumber:Data Diolah, (2020) 
Berdasarkan tabel 2. diatas, diketahui nilai DW 0.996 nilai ini akan dubandingkan dengan nilai tabel signifikan 5\% dengan $(\mathrm{n}=50)$, jumlah variable independent $(\mathrm{k}=4)$, nilai DL (1.3779), dan nilai DU (1.7214). karena DW terletak antara DU dan (4-DU) atau sama dengan $1.7214<0.996<$ 2.2786, maka dapat disimpulkan bahwa model regesi dalam penelitian tersebut tidak terjadi autokorelasi.

\section{Uji Heterokedastisitas}

\section{Gambar 2. Grafik Scatterplot}

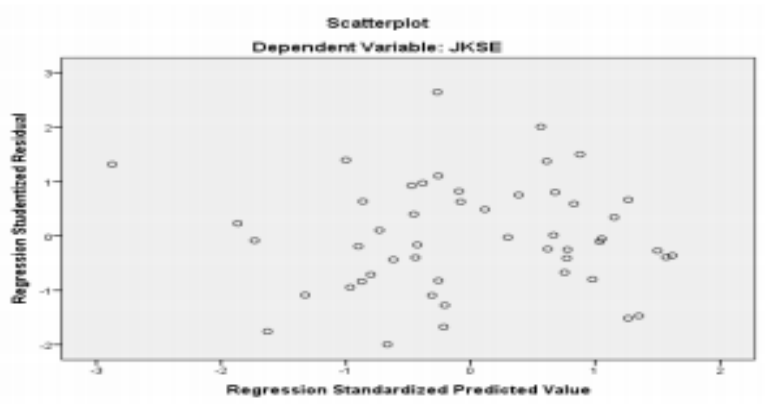

Sumber:Data Diolah, (2020)

Dari Gambar 2. di atas dapat diketahui bahwa titik-titik tidak membentuk pola yang jelas, dan titik-titik menyebar diatas dan dibawah angka 0 pada sumbu $Y$, maka ini menunjuka tidak terjadi heterokedastisitas.

\section{Uji Regresi Linier Berganda}

\section{Uji F}

Tabel 3. Hasil Uji F

ANOVA ${ }^{3}$

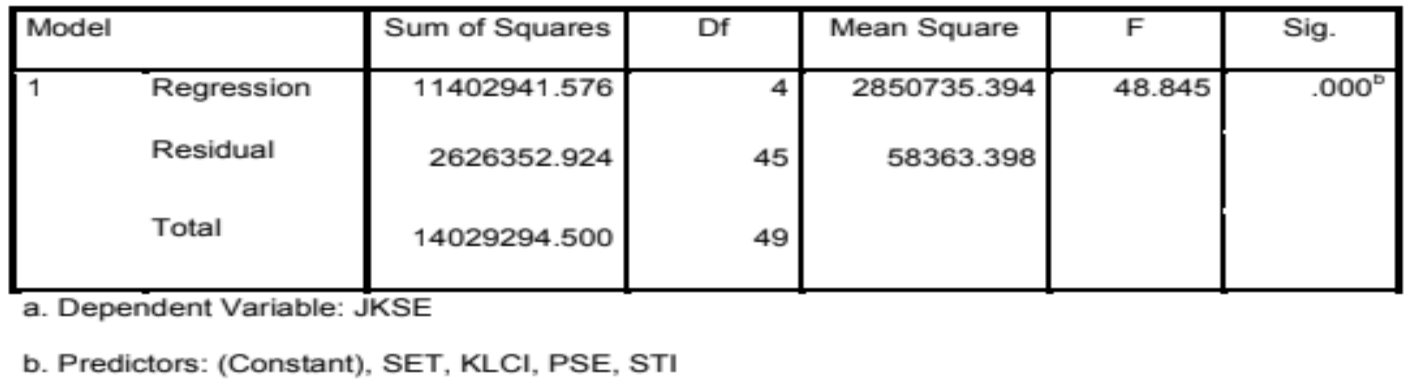

Sumber : Data Diolah, (2020)

Tabel 3. Hasil pengujian uji $\mathrm{F}$ menunjukan nilai signifikan yang diperoleh adalah 0,000. Karena nilai sig. lebih keccil dari 0,05 maka $\mathrm{H} 0$ ditolak dan $\mathrm{H} 1$ diterima sehingga dapat disimpulkan bahwa variabel Strait Time Index, Kuala Lumpur Composite Index, Phillipine Stock Exchange dan Stock Exchange of Thailand secara simultan berpengaruh terhadap variabel Jakarta Composite Index (JKSE) yang terdaftar di BEI.

\section{Uji t}


Tabel 4. Hasil Uji t

\begin{tabular}{|c|c|c|c|c|c|c|}
\hline \multicolumn{7}{|c|}{ Coefficients $^{a}$} \\
\hline \multirow{2}{*}{\multicolumn{2}{|c|}{ Model }} & \multicolumn{2}{|c|}{ Unstandardized Coefficients } & \multirow{2}{*}{$\begin{array}{c}\text { Standardized } \\
\text { Coefficients } \\
\text { Beta }\end{array}$} & \multirow[b]{2}{*}{$\mathrm{t}$} & \multirow[b]{2}{*}{ Sig. } \\
\hline & & B & Std. Error & & & \\
\hline \multirow[t]{5}{*}{1} & (Constant) & 804.445 & 992.522 & & .811 & .422 \\
\hline & STI & .195 & .262 & .073 & .745 & .460 \\
\hline & $\mathrm{KLCl}$ & -2.330 & .569 & -.314 & -4.098 & .000 \\
\hline & PSE & .265 & .112 & .192 & 2.359 & .023 \\
\hline & SET & 3.914 & .428 & .775 & 9.135 & .000 \\
\hline
\end{tabular}

Sumber : Data Diolah, (2020)

\section{Uji Hipotesis}

Tabel 4. Hasil penguji0an uji t menunjukkan nilai signifikansi untuk setiap variabel independen. Dari hasil pengujian 4 variabel independen dapat diketahui bahwa :

H1 : Strait Time Index (STI) mempunyai nilai signifikansi sebesar 0,460 lebih besar dari 0,05, artinya strait time index berpengaruh positif tetapi tidak signifikan terhadap Jakarta Composite Index (JKSE).

H2 : Kuala Lumpur Composite Index (KLCI) mempunyai nilai signifikan sebesar 0,000, nilai ini lebih kecil dari 0,05, artinya Kuala Lumpur Composite Index berpengaruh positif dan signifikan terhadap Jakarta Composite Index (JKSE).

H3 : Phillipine Stock Exchange (PSE) mempunyai nilai signifikan sebesar 0,023, nilai ini lebih kecil dari nilai 0,05, artinya Phillipine Stock Exchange berpengaruh positif dan signifikan terhadap Jakarta Composite Index (JKSE).

H4 : Stock Exchage of Thailand (SET) mempunyai nilai signifikan sebesar 0,000 nilai ini lebih kecil dari 0,05, artinya Stock Exchange of Thailand berpengaruh positif dan signifikan terhadap Jakarta Composite Index (JKSE).

\section{Pembahasan}

1. Hubungan kinerja Strait Time Index Singapura (X1) terhadap Jakarta Composite Index (Y).

Hasil penelitian menunjukkan bahwa variabel Strait Time Index Singapura berpengaruh positif tetapi tidak signifikan terhadap Jakarta CompositeIndex, hal ini berarti sesuai dengan teori yang menyatakan bahwa Stait Time Index Singapura berpengaruh terhadap Jakarta Composite Index.

2. Hubungan kinerja Kuala Lumpur Composite Index (X2) terhadap Jakarta Composite Index (Y).

Hasil penelitian menunjukkan bahwa variabel Kuala Lumpur Composite Index berpengaruh positif dan signifikan terhadap Jakarta Composite Index, hal ini berarti sesuai dengan teori 
yang menyatakan bahwa Kuala Lumpur Composite Index berpengaruh terhadap Jakarta Composite Index.

3. Hubungan kinerja Phillipine Stock Exchange Indeks (X3) terhadap Jakarta Composite Index (Y).

Hasil penelitian menunjukkan bahwa variabel Phillipine Stock Exchange berpengaruh positif dan signifikan terhadap Jakarta Composite Index, hal ini berarti tidak sesuai dengan teori yang menyatakan bahwa Phillipine Stock Exchange berpengaruh negatif terhadap Jakarta Composite Index. Kemungkinan dikarenakan sampel penelitian lebih besar daripada rata-rata populasi sesungguhnya.

4. Hubungan kinerja Stock Exchange Of Thailand (X4) terhadap Jakarta Composite Index (Y).

Hasil penelitian menunjukkan bahwa variabel Stock Exchange OfThailand berpengaruh positif dan signifikan terhadap Jakarta Composite Index, hal ini berarti sesuai dengan teori yang menyatakan bahwa Stock Exchange Of Thailand berpengaruh terhadap Jakarta Composite Index.

5. Hubungan Strait Time Index Singapura, Kuala Lumpur Composite Index, Phillipine Stock Exchange Indeks, Stock Exchange Of Thailand terhadap Jakarta Composite Index.

Hasil penelitian menunjukan nilai sigifikan yang diperoleh adalah 0,000. Hal ini berarti secara simultan variabel Strait Time Index, Kuala Lumpur Composite Index, Phillipine Stock Exchange dan Stock Exchange OfThailand berpengaruh terhadap Jakarta Composite Index yang terdaftar di BEI.

\section{PENUTUP}

\section{Kesimpulan}

Berdasarkan penelitian menganai analisis hubngan pasar modal ASEAN dengan pasar modal Indonesia yang terdaftar di Bursa Efek Indonesia terdapat beberapa kesimpulan sebagai berikut:

1. Bursa Singapura mempunyai hubungan yang tidak signifikan dengan bursa Indonesia dari hasil uji t menyatakan bahwa nilai sig $<0,05$ sehingga apabila bursa Singapura naik maka tidak mempunyai hubungan dengan bursa Indonesia (tidak ikut naik)

2. Dalam penelitian kali ini Bursa Malaysia mempunyai hubungan yang signifikan dengan bursa Indonesi dari hasil uji t menyatakan nilai sig $>0,05$ dimana apabila bursa Malaysia naik maka Bursa Indonesia juga akan naik.

3. Hasil penelitian uji t menyatakan bursa Fillipina mempunyai hubungan yang signifikan dengan bursa Indonesia artinya jika bursa Fillipina naik maka bursa Indonesia juga ikut naik.

4. Hasil penelitian menunjukan bahwa bursa Thailand mempunyai hubungan yang signifikan dengan bursa Indonesia artinya jika bursa Thailand naik maka bursa Indonesia juga akan naik. 
1. Dari hasi penelitian dan pembahasan membuktikan bahwa H2 Kuala Lumpur Stock Exchange, H3 Phillipine Stock Exchange, H4 Stock Exchange Of Thailand diterima sedangkan H1 Singapura Exchange Limited ditolak.

\section{Saran}

1. Bagi Investor

Setiap investor yang akan melakukan investasi di Bursa Efek Indonesia (BEI) diharapkann agar terlebih dahulu menganalisis pergerakan setiap indeks saham yang ada, serta melihat kondisi perekonomian yang terjadi di beberapa negara ASEAN yang dianggap mempengaruhi perekonomian negara Indonesia.

2. Bagi Peneliti Selanjutnya

Bagi peneliti selanjutnya penelitian ini dapat dijadikan sebagai acuan untuk penelitian berikutnya yang memebahas berkaitan dengan hubungan pasar modal. Bagi para peneliti selanjutnya duharapkan untuk menganalisa lebih lanjut tentang indeks harga saham dengan menggunakan data harian dalamhal ini closing price indeks harga saham dan volume perdagangan serta memperpanjang waktu penelitian agar menghasilkan data yang lebih baik.

\section{DAFTAR PUSTAKA}

Fahmi, Irham. 2015. Pengantar manajemen keuangan teori dan soal jawab, Bandung: Penerbit Alfabeta

Sunariyah, 2013. Pengantar penetahuan pasar modal. Yogyakarta : UPP-STIM YKPN.

Jogiyanto. 2015. Teori portofolio dan analisis investasi. Yogyakarta: Penerbit Ghalia Indonesia.

Tandelin. 2013. Portofolio dan Investasi Teori Aplikasi. Edisi Keempat. Yogyakarta : Kanisius

Kasmir. 2013. Analisis Laporan Keuangan. Edisi Ketigabelas. Jakarta : PT Raja Grafindo Persada

Darmaji dan Fakhrudin. 2014. Pasar modal di Indonesia. Edisi. Keempat. Jakarta : Salemba Empat.

Masyhuri. 2013. Metodologi Penelitian- Pendekatan praktis dan aplikatif. Bandung : PT Refika aditama

Sudarmanto, Gunawan. 2013. Statistik terapan berbasis computer dengan program IBM SPSS Statistic 19. Jakarta : Mitra Wacana Media

Sugiyono. 2017. Metode penelitian pendidikan pendekatan Kuantitatif, Kualitatif dan R\&D. Bandung : Alfabeta

Ghozali, Imam. 2013. Aplikasi Analisis Multivariate dengan Program IBK SPSS 21 Update PLS Regresi. Semarang : Badan Penerbit Universitas Diponegoro

Gunawan, Imam. 2015. Pengantar statistika inferensial. Jakarta

Rasyidin. 2016. Integrasi Pasar Modal ASEAN Pasca Pemberlakuan MEA Jurnal Visioner dan Strategi Vol. 5 no. 2 September 2016. 
Luh Gede Sri Artini, Nyoman Tri Aryati, dkk. 2017. Analisis Fundamental Makro dan Integrasi Pasar Saham Dunia Dengan Bursa Efek Indonesia. Vol. 11 no. 2 Agustus 2017.

Ardina Puspitasari, Hermanto Siregar, Trias Andati. 2015. Analisis Integrasi Bursa Saham ASEAN 5 (Analysis of Stock Exchange Integration of ASEAN 5). Jurnal Ekonomi dan Kebijakan Pembangunan Vol. 4 no. 22015.

E. Walewangko, I.S.Saerang, J.B. Maramis. 2018. Analisis Integrasi Saham Bursa Efek Inonesia dan Beberapa Bursa Efek Negara ASEAN Periode Januari 2016 - 2017. Jurnal EMBA Vol. 6 no. 4 September 2018.

Darwanti, Suli dan Tri Santoso. 2015. Pengaruh perubahan nilai tukar, suku bunga, harga minyak duni dan indeks saham dow jones terhadap Indeks harga saham gabungan pada pasar modal di negara-negara ASEAN. The 7th NCFB and Doctoral Colloquium. ISSN NO : $1978-6522$.

Jurgen H. Waworundeng, Paulina Van Rate. 2018. Analisis Hubungan Pasar Modal Asean dengan Pasar Modal Di Bursa Efek Indonesia. Jurnal EMBA Vol.6 no.1 Januari 2018.

Jeina, Mailangkay. 2013. Integrasi Pasar Modal Indonesia dan Beberapa Bursa Di Dunia. Jurnal EMBA. Fakultas Ekonomi dan Bisnis : Universitas Sam Ratulangi Manado. Hal. 722-731

Bursa Efek Indonesia. 2015. Buku Pedoman Indeks Harga Saham Bursa Efek Indonesia. Jakarta.

www.investing.com

www.yahoo.finance

www.asean.org

www.investopedia.com

$\underline{\text { www.businessdictionary.com }}$

www.kemenkeu.go.id 